\title{
Nephrogenic adenomas of the urinary system: a clinicopathologic analysis of 30 cases
}

\author{
Üriner sistemin nefrojenik adenomları: 30 vakanın klinikopatolojik analizi
}

\author{
Berna Aytac Vuruskan ${ }^{1}$, Ezgi Isil Turhan ${ }^{2}$, Hakan Vuruskan ${ }^{3}$, Ismet Yavascaoglu ${ }^{3}$ \\ 1 Uludag University Faculty of Medicine, Department of Pathology, Bursa, Turkey \\ 2 Bursa City Hospital, Bursa, Department of Pathology, Turkey \\ 3 Uludag University Faculty of Medicine, Department of Urology, Bursa, Turkey
}



\begin{abstract}
Özet
Amaç: Nefrojenik adenom (NA), en sık mesane olmak üzere üriner sistemin değişik yerlerinde oluşan benign bir lezyondur. Üriner sistem irritasyonu, kronik inflamasyon, geçirilmiş ürolojik cerrahi ve intravezikal enstrümantasyon ile ilişkilidir. Çalışmamızda, nefrojenik adenom tanısı almış olguların klinikopatolojik özelliklerinin ve sonuçlarının güncel literatür bilgileri eşliğinde incelenerek sunulması amaçlanmıştır.

Gereç ve Yöntemler: Çalışmamıza Şubat 2005- Kasım 2017 yılları arasında Nefrojenik adenom patolojik tanısı almış 30 hasta dahil edildi.

Bulgular: 30 hastanın \% 63,3'ü erkekti ve ortalama yaş 60 olarak bulundu. Olgular mesane $(\% 86,6)$, üreter $(\% 6,7)$ ve üretra $(\% 6,7)$ yerleşimliydi. En sık hematüri $(\% 36,7)$ klinik bulgusu görülmüştü. Hastaların \%26,7’sinde eşlik eden mesane kanseri öyküsü mevcuttu ancak hiçbir hastada nefrojenik adenom tanısı sonrası yeni gelişen mesane kanseri mevcut değildi. İlk rezeksiyon sonrası takip sistoskopilerinde $\% 10$ hastada rekürrens görüldü.

Sonuç: Nefrojenik adenomlar nonspesifik semptom ve endoskopik bulgular gösteren nadir lezyonlardır. Bu nedenle doğru tanı rezeksiyon materyalinin histolojik değerlendirilmesi ile konulmalıdır.
\end{abstract}

Anahtar Kelimeler: nefrojenik adenom, ürotelyal lezyon, mesane, üreter.

\section{Abstract}

Objective: Nephrogenic adenomas (NA) are benign lesions that may occur in several sites throughout the urinary tract, from the renal pelvis to urethra, and especially in the bladder. They are strongly associated with urinary tract irritation, chronic inflammation, previous urologic surgery, and intravesical instrumentations. Our study aims to evaluate and present the clinicopathologic characteristics and findings of cases that were diagnosed with nephrogenic adenoma accompanied by relevant information from the literature.

Material and Methods: Our study includes 30 patients who were pathologically diagnosed with NA from February 2005 to November 2017.

Results: Among these patients, $63.3 \%$ were males and mean age was 60 years. The most common site of occurrence was the bladder (86.6\%), followed by the ureter $(6.7 \%)$ and the urethra (6.7\%). Most patients presented with hematuria (36.7\%). History of concurrent bladder cancer was present in $26.7 \%$ of patients, but there were no cases of de novo bladder cancer diagnosed after NA. Recurrence of NA after initial resection occurred in only $10 \%$ of patients who underwent follow-up cystoscopy. Nephrogenic adenoma is a rare lesion associated with nonspecific symptoms and endoscopic features. Definite diagnosis must be made after histological analysis of resected specimens.

Conclusion: Nephrogenic adenoma is a rare lesion associated with nonspecific symptoms and nonspesific endoscopic features. A definite diagnosis must be after histological analysis of resected specimens.

Keywords: nephrogenic adenoma, urothelial lesion, bladder, ureter

The study was approved by the Ethics Committee of Bursa City Hospital (Approval number: 2021-7/5) (Date: 2021, April 21). All research was performed in accordance with relevant guidelines/regulations, and informed consent was obtained from all participants. 


\section{INTRODUCTION}

Nephrogenic adenomas (NA) are benign lesions which originate from urothelial epithelium and occur in both adults and children (1). While they are more prevalent among the elderly and males, $10 \%$ are encountered in children $(1,2)$. Throughout the urinary tract, NA are most commonly found in the bladder, but may also occur in the ureter, urethra, and renal pelvis (3-5). When it was initially identified, it was considered a hamartoma of the bladder, but was later named nephrogenic adenoma due to its structure similar to renal tubules $(6,7)$. The literature also implements the terminology of nephrogenic metaplasia, metanephric metaplasia, adenomatoid tumor, and adenomatoid metaplasia (5). Etiologic factors include chronic irritation, catheterization, intravesical kemotherapy treatment for urothelial cancer, stone formation, urinary system infection, and history of urinary surgery (1). A few case series have shown coexisting bladder cancer (1). Few publications with large patient series are available in the literature. Therefore, there is contradictory information about the evaluation and follow-up of these lesions.

Our study aims to evaluate and present the clinicopathologic characteristics and findings of cases that were diagnosed with nephrogenic adenoma accompanied by relevant information from the literature.

\section{MATERIAL AND METHODS}

This retrospective study included 30 patients who were diagnosed with metanephric metaplasia, nephrogenic metaplasia, and nephrogenic adenoma in Uludağ University Training and Research Hospital from February 2005 to November 2017. Clinical and follow-up information were collected from patient records. Histopathologic findings and relevant slides of the tissue samples were obtained from the Pathology archive. Clinical history, symptoms, and histologic findings of the cases were rereviewed. Ethical committee approval was not obtained because our study was performed retrospectively on patient files.

\section{RESULTS}

Clinicopathologic characteristics of the cases are presented in Table $1.19(63,3 \%)$ of the cases diagnosed with NA were males and $11(36,7 \%)$ were females. The age range of the cases varied between 6 and 77, mean age was 60 years. Two patients were children at aged 6 and 11. Site of occurrence was the bladder in a majority of the cases $(86,7 \%)$. The most common symptoms were hematuria (36,7\%) and recurrent urinary tract infections (23,3\%). Relevant urologic events and medical histories of the cases are presented in Table 1. Papillary or polypoid appearance in cystoscopic evaluation was noted in almost all cases, and differential diagnosis of urothelial carcinoma had been attempted to be established. In total, 23 cases $(76,6 \%)$ underwent biopsy, 6 (20\%) underwent transurethral resection, one patient $(3,3 \%)$ underwent cystectomy and one patient $(3,3 \%)$ underwent nephroureterectomy. Urothelial carcinoma was found in 8 patients $(26,7 \%)$ who underwent TUR and cystectomy.

Three patients were found to have NA recurrence during the 3 years follow-up period after cystoscopy. Recurrence developed within the first year of follow-up of two patients and in the second year in one patient. None of the patients developed malignancy. Histopathologic assessment revealed various morphologic findings of the lesions. Twenty-five cases $(83,3 \%)$ showed mixed pattern, 4 cases $(13,3 \%)$ papillary and polypoid pattern and one case (3,3\%) fibromyxoid growth pattern (Figure 1, Figure 2).

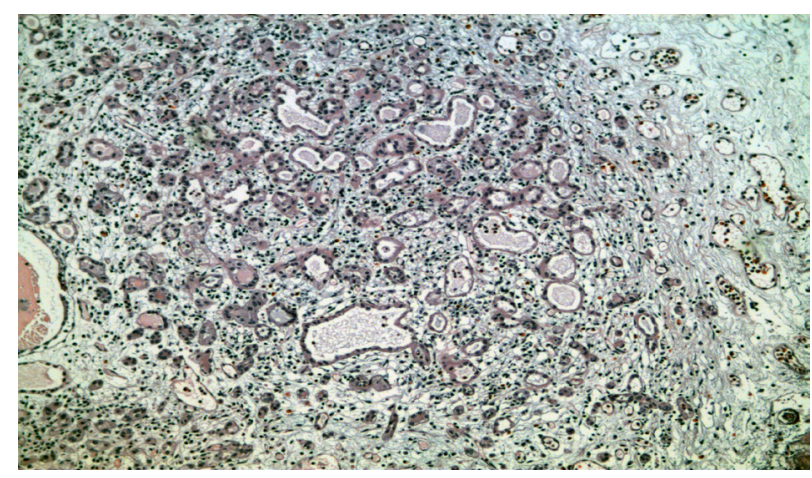

Figure 1. A-B) Tubular and tubulocystic growth pattern(H\&E; x100) 
Table. Clinicopathological Features of Nephrogenic Adenomas ( $\mathrm{n}=30$ cases)

\begin{tabular}{|c|c|}
\hline Features & Number(\%) \\
\hline \multicolumn{2}{|l|}{ Age } \\
\hline Mean & 60 \\
\hline Average & $6-77$ \\
\hline \multicolumn{2}{|l|}{ Gender } \\
\hline Female & $11(36,7)$ \\
\hline Male & $19(63,3)$ \\
\hline \multicolumn{2}{|l|}{ Recurrence } \\
\hline Absent & $27(90)$ \\
\hline Exist & $3(10)$ \\
\hline \multicolumn{2}{|l|}{ Localization } \\
\hline Urinary bladder & $26(86,6)$ \\
\hline Ureter & $2(6,7)$ \\
\hline Ürethra & $2(6,7)$ \\
\hline \multicolumn{2}{|l|}{ Symptoms } \\
\hline Haematuria & $11(36,7)$ \\
\hline Asymptomatic & $3(10)$ \\
\hline Incontinence & $3(10)$ \\
\hline Dysuria & $2(6,7)$ \\
\hline Recurrent urinary tract infection & $7(23,3)$ \\
\hline Stone & $5(16,7)$ \\
\hline Urinary retention & $4(13,3)$ \\
\hline \multicolumn{2}{|l|}{ Histology } \\
\hline Mix & $25(83,3)$ \\
\hline Papillary, polypoid & $4(13,3)$ \\
\hline Fybromixoid & $1(3,3)$ \\
\hline \multicolumn{2}{|l|}{ Concomitant Lesion } \\
\hline Inflamation & $12(40)$ \\
\hline Urothelial carcinoma & $8(26,6)$ \\
\hline Other tumors & $5(16,7)$ \\
\hline Renal failure & $5(16,7)$ \\
\hline \multicolumn{2}{|l|}{ Etiology } \\
\hline Undergone surgery & $11(36,7)$ \\
\hline Urinary tract infection & $8(26,6)$ \\
\hline Stone & $5(16,7)$ \\
\hline Intravesicle treatment & $3(10)$ \\
\hline Catheterization & $8(26,6)$ \\
\hline
\end{tabular}




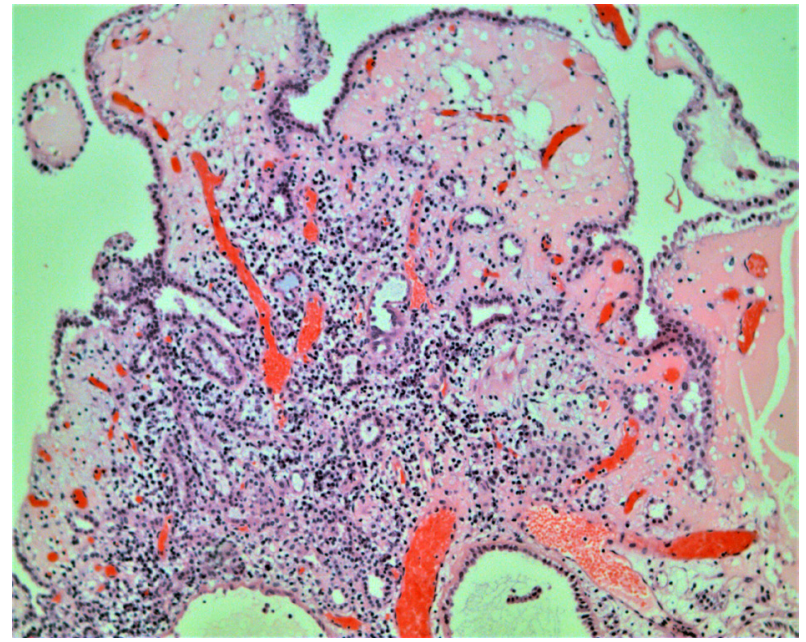

Figure 2. A) Papillary and polypoid growth pattern (H\&E; x100)

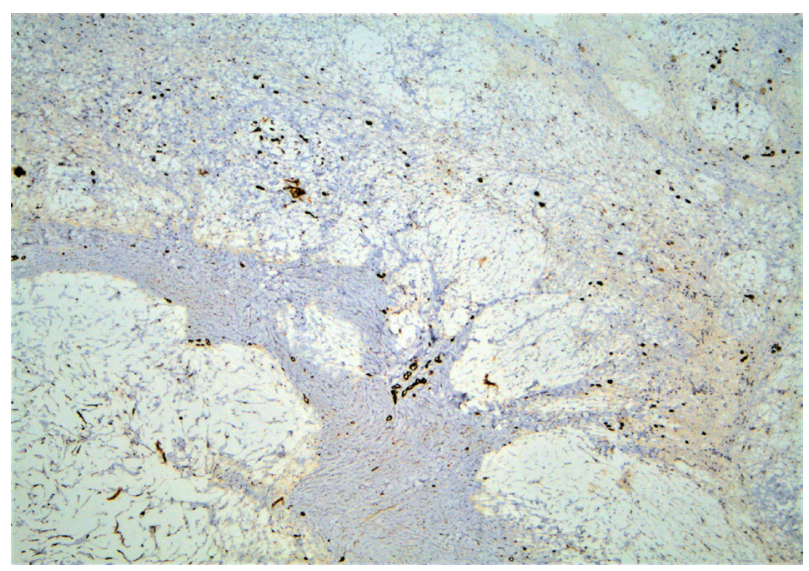

Figure 3. CK7 positivity ( IHC; x100)

Lesions were generally localized in the mucosa and lamina propria. The only lesion localized in the muscularis propria was the case with the fibromyxoid growth pattern located in the ureter. Some cases were found to have immunohistochemical positivity with renal tubule cell markers such as CK7, CD10, and PAX-8 (Figure 3).

\section{DISCUSSION}

There are varying opinions in the literature related to the mechanisms of nephrogenic adenoma development. Some articles indicate metaplastic changes due to injury and chronic inflammation of urothelial epithelium. Other authors emphasize that adenoma formation is due to the proliferation of renal tubule cells implanted in different areas of the urinary system, similar to the formation of endometriosis $(2,8,9)$.

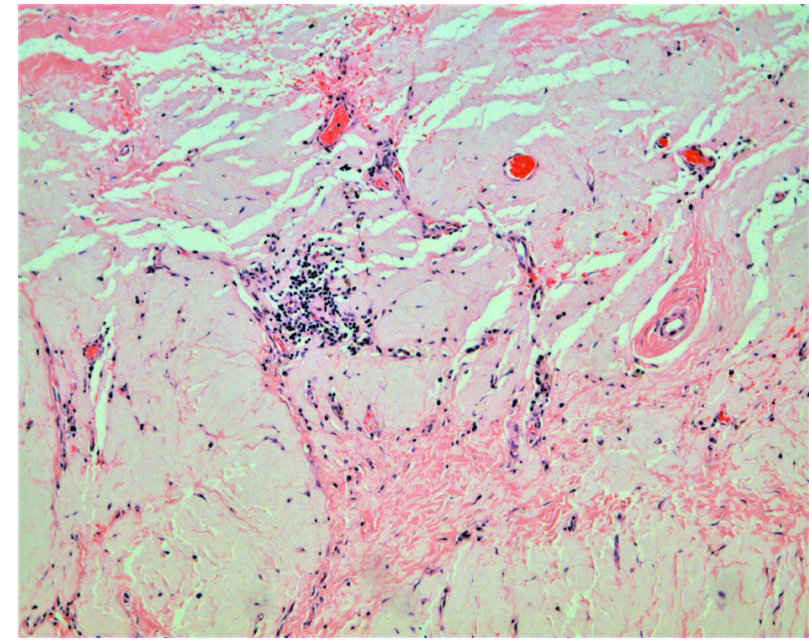

Figure 2. B) Fibromyxoid growth pattern (H\&E; x100)

The most commonly identified clinical signs are lower urinary tract symptoms and hematuria. More rarely, retention, dysuria, and recurrent infections may also occur. Cases may also be asymptomatic and incidentally detected $(1,3)$. In our case series, the majority of patients had signs of hematuria. According to the literature, patients may have urological history of recurrent urinary tract infections, benign prostate hyperplasia, interstitial cystitis, or urothelial carcinoma (2). Among our cases, urothelial carcinoma was detected in eight patients. Five of the tumors were noninvasive and three were invasive. Four of the noninvasive tumors were low-grade and one was high-grade, while all of the invasive tumors were high-grade. Additionally, other than bladder cancer, three women had ovarian, breast, and endometrium tumors, and two male patients had prostate tumor diagnoses.

Cystoscopy findings of nephrogenic adenoma are nonspecific. They generally appear as a single flat lesion or multiple polypoid or papillary lesions (10). Lesions are typically smaller than $1 \mathrm{~cm}$ but may be larger than $7 \mathrm{~cm}$ (8). Papillary lesions may mimic urothelial carcinoma or chronic cystitis. Single layer lesions may be confused with urothelial carcinoma in situ (10). In all of our cases, resections or biopsies were performed with pre-diagnosis of urothelial carcinoma.

Definite diagnosis of the lesions can be made with histopathologic evaluation (11). Various growth patterns including tubular, tubulocystic, polypoid, papil- 
lary, fibromyxoid, and flat growth patterns have been defined in histopathologic examination $(11,12)$. The most common growth pattern is tubular. Tubule structures are lined with cuboidal or low columnar cells, and rarely as hobnail cells with narrow cytoplasms (11). Cytoplasms are often eosinophilic but may have a transparent appearance. No pronounced cellular atypia and necrosis are detected. Mitosis is very rare. Tubules are usually separated from each other and randomly distributed in the lamina propria. Sometimes prominent basement membrane material may be seen surrounding the tubules. The tubulocystic pattern exhibits tubules or cysts with cystic dilations containing eosinophilic or basophilic material in their lumens. Lumens may show eosinophilic secretions similar to thyroid follicles. Similarly, the polypoid or papillary growth pattern consists of dilated structures lined with a single layer of cuboidal or low columnar epithelial cells. Papillary formations may be prominently simple or contain slight branches. Other growth patterns include solid islets, cell cords, and fibromyxoid growth, consisting of spindle cells in myxoid stroma $(11,12)$. Nephrogenic adenomas do not typically exhibit widespread invasion; however they may exhibit focal or superficial involvement of the muscularis propria (13).

Immunohistochemically, nephrogenic adenomas are positively stained by renal tubule cell markers such as CK7, CD10, AMACR, PAX-2, and PAX-8 (13). GATA-3, an emerging marker of urothelial lesions (9). McDaniel et al. (14) showed GATA-3 expression in 40\% of NA cases but it is not a useful marker in differentiating between NA and flat urothelial atypia. In differential diagnosis, nephrogenic adenomas may be most commonly mistaken for clear cell carcinomas. This rare tumor also consists of tubular, cystic, and papillary structures, similar to nephrogenic adenomas. However, the presence of large clear cytoplasm, nuclear pleomorphism and hyperchromia, necrosis, extensive invasion to muscularis propria, detection of lymphovascular invasion, and high ki67 proliferative index are all findings in favor of carcinoma (15). Other differential modalities include urothelial papilloma, papillary urothelial carcinoma, microcystic urothelial carcinoma, nested variant of urothelial carcinoma, and prostatic adenocarcinoma, especially in lesions located in the urethra $(3,5)$.
General treatment approach is surgical resection in order to determine diagnosis and improve symptoms $(1,3,9)$. There are no guidelines on nephrogenic adenoma follow-ups. The recurrence rate varies according to studies, but long-term follow ups report recurrence rates between $0.5-80 \%(2,9)$. Although recurrence times vary between 2-24 months, recurrence, on average, occurs within the first year (3). In our study, recurrence occurred three times in one-year intervals in a 12-year-old male patient, the first of which was one year after initial resection as well as in a 77-year-old female patient two years after resection, and in a 76-yearold male patient one year after resection. However, none of the patients developed malignancy.

The preneoplastic potential of nephrogenic adenomas is still controversial (16). Hartman et al. reported a nephrogenic adenoma patient who developed clear cell carcinoma in the recurrence period and demonstrated that all three lesions (initially nephrogenic adenoma, then recurrence, and clear cell carcinoma) all had similar genetic changes (16). Pycha et al. reported aberrations of chromosome 7 and 9 that were detected in nephrogenic adenoma, therefore indicating preneoplastic potential (17). The most important limitation of our study is the narrow case series. However, the majority of large case series and current literature indicate that nephrogenic adenoma is a benign reactive lesion and is not associated with the development of bladder cancer (18).

\section{CONCLUSION}

Nephrogenic adenomas are lesions which can clinically and histologically mimic malignancy. It is important to increase nephrogenic adenoma awareness of clinicians and pathologists in order to correctly interpret endoscopic and morphological findings in the presence of suspicious etiological factors. Nephrogenic adenomas can show malignant potential. Caution should be exercised due to the high risk of recurrence and cases should be kept under long-term follow-up.

Main Points;

1. Nephrogenic adenomas are lesions which can clinically and histologically mimic malignancy.

2. It is important to increase nephrogenic adenoma awareness of clinicians and pathologists in order to 
correctly interpret endoscopic and morphological findings in the presence of suspicious etiological factors.

\section{Acknowledgment}

No acknowledgments to declare.

\section{Conflict of Interest}

All authors declared that there is no conflict of interest.

\section{Financial Disclosure}

The authors declared that this study has received no financial support.

\section{Ethical Approval}

The study was approved by the Ethics Committee of Bursa City Hospital (Approval number: 2021-7/5) (Date: 2021, April 21). The study protocol conformed to the ethical guidelines of the Helsinki Declaration.

\section{REFERENCES}

1. Gordetsky J, Gennaro KH, Selph JP, Rais-Bahrami S. Nephrogenic Adenoma: Clinical Features, Management, and Diagnostic Pitfalls. Urology. 2016; 95:29-33.

2. Venyo AK. Nephrogenic Adenoma of the Urinary Bladder: A Review of the Literature. Int Sch Res Notices. 2015; 2015:704982.

3. Kuzaka B, Pudełko P, Powała A, Górnicka B, Radziszewski P. Nephrogenic adenoma of the urinary bladder: a report of three cases and a review of the literature. Ann Transplant. 2014; 19:153-156.

4. Rensing AJ, Koenig JF, Vricella GJ, Sehn JK. Nephrogenic adenoma of the pediatric ureter. J Urol. 2015; 193:1377-1378.

5. Kunju LP. Nephrogenic adenoma: report of a case and review of morphologic mimics. Arch Pathol Lab Med. 2010; 134(10):1455-1459.

6. Davis TA. Hamartoma of the urinary bladder. Northwest Med. 1949; 48:182-185.

7. Friedman NB, Kuhlenbeck H. Adenomatoid tumors of the bladder reproducing renal structures (nephrogenic adenomas). J Urol. 1950; 64:657-670.

8. López JI, Schiavo-Lena M, Corominas-Cishek A et al. Nephrogenic adenoma of the urinary tract: clinical, histological, and immunohistochemical characteristics. Virchows Arch. 2013; 463:819-825.

9. Turcan D, Acikalin MF, Yilmaz E, Canaz F, Arik D. Nephrogenic adenoma of the urinary tract: A 6-year single center experience. Pathol Res Pract. 2017; 213(7):831-835.

10. Porcaro AB, D’Amico A, Ficarra V et al. Nephrogenic adenoma of the urinary bladder: our experience and review of the literature. Urol Int. 2001; 66(3):152-155.

11. Oliva E, Young RH. Nephrogenic adenoma of the urinary tract: a review of the microscopic appearance of 80 cases with emphasis on unusual features. Mod Pathol. 1995; 8(7):722-730.

12. Dropkin BM, Giannico GA, Reisz PA, Penson DF, Hsi RS. Fibromyxoid Nephrogenic Adenoma in the Ureter. J Endourol Case Rep. 2018; 4(1):97-99.

13. Safaei A, Farzaneh MR, Amin Sharifi AR. Immunohistochemistery study in a case of nephrogenic adenoma of bladder. Iran J Med Sci. 2012; 37(2):137-140.

14. A.S. McDaniel, A.M. Chinnaiyan, J. Siddiqui, J.K. McKenney, R. Mehra. Immunohistochemical staining characteristics of nephrogenic adenoma using the PIN-4 cocktail (p63, AMACR, and CK903) and GATA-3, Am. J. Surg. Pathol. 2014; 38:1664-1671.

15. Herawi M, Drew PA, Pan CC, Epstein JI. Clear cell adenocarcinoma of the bladder and urethra: cases diffusely mimicking nephrogenic adenoma. Hum Pathol. 2010; 41(4):594-601.

16. Hartmann A, Junker K, Dietmaier W et al. Molecular evidence for progression of nephrogenic metaplasia of the urinary bladder to clear cell adenocarcinoma. Hum Pathol. 2006; 37(1):117-120.

17. Pycha A, Mian C, Reiter WJ et al. Nephrogenic adenoma in renal transplant recipients: a truly benign lesion? Urology. 1998; 52(5):756-761.

18. Yi Y, Wu A, Cameron AP. Nephrogenic adenoma of the bladder: a single institution experience assessing clinical factors. Int Braz J Urol. 2018; 44(3):506-511. 